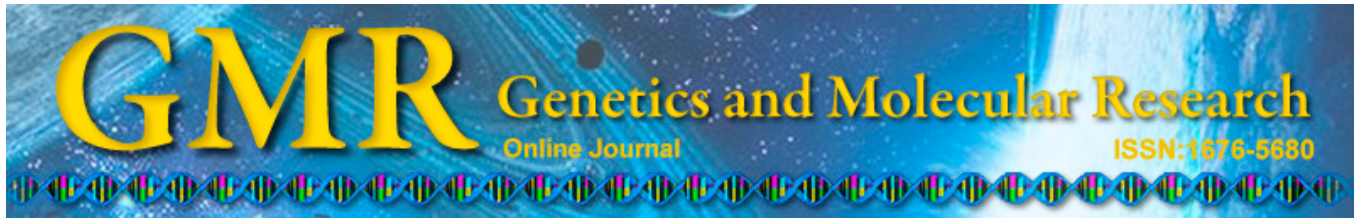

\title{
Assessing the genotoxicities of sparteine and compounds isolated from Lupinus mexicanus and $L$. montanus seeds by using comet assay
}

\author{
M.R. Silva ${ }^{1}$, C.M. Alvarez ${ }^{1}$, P.M. García ${ }^{2}$ and M.A. Ruiz ${ }^{2}$ \\ ${ }^{1}$ Genetic Laboratory, Department of Cellular and Molecular Biology, \\ University Center for Biological and Agricultural Sciences, \\ Guadalajara University, Guadalajara, Jalisco, México \\ ${ }^{2}$ Biotechnology Laboratory, Department of Botany and Zoology, \\ University Center for Biological and Agricultural Sciences, \\ Guadalajara University, Guadalajara, Jalisco, México \\ Corresponding author: C.M. Alvarez \\ E-mail: calvarez@cucba.udg.mx
}

Genet. Mol. Res. 13 (4): 10510-10517 (2014)

Received January 15, 2014

Accepted May 9, 2014

Published December 12, 2014

DOI http://dx.doi.org/10.4238/2014.December.12.12

\begin{abstract}
The genus Lupinus is widely distributed. Its seeds are used for animal and human food, and Lupinus possesses pharmacological potential because of its high content of quinolizidine alkaloids and flavonoids; however, there is little available information about its genotoxicity. We used the comet assay and staminal nuclei of Tradescantia (clone 4430) to evaluate the in vitro genotoxicity of 4 concentrations $(0.01,0.1,0.5$, and $1.0 \mathrm{mM})$ of alkaloid extracts of Lupinus mexicanus and Lupinus montanus, flavonoids of L. mexicanus, and commercial sparteine; nitrosodiethylamine was used as a positive control and untreated nuclei were used as a negative control. All concentrations of $L$. mexicanus and $L$. montanus showed significant genotoxic activity $(\mathrm{P} \leq 0.05)$. A similar behavior was observed for flavonoid extracts of $L$. montanus except the $1.0 \mathrm{mM}$ concentration. Sparteine showed genotoxic activity only at $0.5 \mathrm{mM}$. The order of
\end{abstract}


genotoxicity of the compounds studied was as follows: $L$. mexicanus $>$ L. montanus $>$ flavonoids of $L$. montanus $>$ sparteine. There is evident genotoxic activity in the compounds that were studied, particularly at lower concentrations $(0.01$ and $0.1 \mathrm{mM})$. Given the limited information about the genotoxicity of the compounds of $L$. mexicanus and L. montanus, further studies are necessary.

Key words: Alkaloids; Lupinus; DNA damage; Comet assay; Genotoxicity test; Genotoxic activity

\section{INTRODUCTION}

The genus Lupinus belongs to the Fabaceae family and comprises about 300 species distributed in the Mediterranean region and America (Dunn, 1979; McVaught, 1987; Ruíz, 1994; Gladstones, 1998). Some of these have been domesticated; their seeds have a protein concentration of $30-35 \%$ and an alkaloid concentration of $0.02 \%$. They are used for food and feed (Gladstones, 1974; Dash and Sgarbieri, 1980; López-Bellido and Fuente, 1986; Egaña et al., 1992; Bunger et al., 1999). The wild species also have high protein content, but in contrast to domesticated lupines, their total concentration of quinolizidine alkaloids is greater than $1 \%$; this is their main chemical defense against predators such as insects, herbivores, and omnivores (Bermúdez-Torres et al., 2009). Symptoms of acute toxicity in animals and humans caused by the consumption of wild lupines include diarrhea, vomiting, respiratory failure, and convulsions (Wink and Hartmann, 1981; Agid et al., 1988). There are no reports of long-term effects; however, the metabolic activation of these compounds in the liver turns them into highly reactive molecules that are capable of reacting with macromolecules such as DNA (Prakash et al., 1999). Some flavonoids, such as genistein-8-C, show genotoxic activity (Boos and Stopper, 2000), but there are controversial data about the genotoxic effects, such as those reported by Rucinska and Gabryelak (2009), which show differences between in vivo and in vitro studies.

Various bioassays can be used to assess the integrity of the genetic material (Zuñiga, 2001). One of the most used methods is the alkaline comet assay that was developed by Singh et al. (1988), which can detect breaks in the DNA strands, alkali-sensitive sites, and incomplete repair sites (Nacci et al., 1996; Belpaeme et al., 1998). The assay (Koppen and Verschaeve, 1996) and its effectiveness were shown by using the nuclei of Tradescantia (Alvarez-Moya et al., 2001); additionally, the assay could be used to examine the genotoxic activity of several natural products.

The alkaloids derived from Lupinus have promising nutritional and therapeutic potentials; however, it is necessary to determine their genotoxic activity. This study used the alkaline comet assay in nuclei from Tradescantia (clone 4430) to assess the genotoxicity of alkaloid extracts of Lupinus mexicanus, L. montanus, flavonoids, and sparteine.

\section{MATERIAL AND METHODS}

\section{Plant material}

Specimens of L. mexicanus and L. montanus were collected in Lagos de Moreno and Nevado de Colima, Jalisco, Mexico; they were classified at the Institute of Botany of the Uni- 
versity of Guadalajara (Voucher No. 853). Mature seeds were separated in order to obtain the extracts and flavonoids and were stored until use.

\section{Obtaining the crude alkaloid extract}

The extracts were obtained from $100 \mathrm{~g}$ seeds of $L$. mexicanus and L. montanus; the seeds were milled, and the flour was degreased in a soxhlet with petroleum ether. The flour was separated from ether by evaporation and was subsequently mixed with $300 \mathrm{~mL} 25 \%$ potassium hydroxide for $3 \mathrm{~h}$; the alkalized flour was then homogenized with $300 \mathrm{~g}$ diatomaceous earth (Merck S.A. de C.V., Distrito Federal, México, CAS 68855-54-9). Then, the flour-earth mixture was placed in columns that were previously prepared with a layer of fiberglass, sand, diatomaceous earth, and sea sand. The extracts were eluted with $500 \mathrm{~mL}$ dichloromethane. The organic phase was recovered and evaporated to dryness at $40^{\circ} \mathrm{C}$ with a rotary evaporator; the presence of alkaloids was immediately determined using Dragendorff reagent (Wysocka and Przybyl, 1994).

\section{Sparteine and flavonoids}

Sparteine (CAS No. 90-39-1) was obtained commercially as sparteine sulfate (Sigma Chemical Company). Flavonoids were obtained from germinated seeds that were homogenized in $80 \%$ methanol $(\mathrm{MeOH})$, and the suspension was placed in an ultrasonic bath for 30 $\mathrm{min}$. The extract was centrifuged and the alkaloids were removed from the supernatant using solid phase extraction on strong cation exchange (10.0 g, Supelco) columns. The loaded SPE columns were washed with $10 \mathrm{~mL} 10 \% \mathrm{MeOH}$ and $10 \mathrm{~mL} \mathrm{MeOH}$; an aliquot of the eluate was evaporated and stored at $-80^{\circ} \mathrm{C}$ prior to the liquid chromatography-mass spectrometry (LCMS) analysis. The rest was freeze-dried in a Labconco lyophilizer (LABCONCO Corporation, USA). The lyophilized extract sample was kept at $-80^{\circ} \mathrm{C}$ until its use in the genotoxic assay (Stobiecki et al., 1997).

The full extracts of $L$. mexicanus and $L$. montanus, as well as the sparteine and flavonoids, were diluted to $0.01,0.1,0.5$, and $1.0 \mathrm{mM}$ and were kept refrigerated until the assessment of their genotoxic activity.

\section{Analysis of flavonoids by LC-MS}

The analysis and identification of the seed flavonoid extracts were performed with 2 LC-MS systems in accordance with Wojakowska et al. (2013).

\section{Maintenance of Tradescantia}

The clone 4430 of Tradescantia (Tradescantia subacaulis x Tradescantia hirsutiflora) was obtained from the Laboratory of Mutagenesis, University Center for Biological and Agricultural Sciences, University of Guadalajara. The plants were kept in a greenhouse at $25^{\circ} \mathrm{C}$ and were watered and vegetatively propagated until use.

\section{Obtaining Tradescantia nuclei}

The staminal nuclei were obtained from the stamens of the flowers of 10 healthy 
plants; they were placed in 2 cold mortars ( 24 per mortar), and $440 \mu \mathrm{L}$ Honda buffer [0.44 M sucrose, 2.5\% Ficoll (type 400), 5\% dextran T-40, $25 \mathrm{mM}$ Tris-HCl, pH 8.5, $10 \mathrm{mM} \mathrm{MgCl}, 10$ $\mathrm{mM} \beta$-mercaptoethanol, and $2.5 \%$ Triton X-100] was added. Homogenization was carried out immediately. The mixture was then filtered through a nylon mesh with a pore opening of 80 $\mu \mathrm{m}$. The nuclei were separated by centrifugation at $3000 \mathrm{rpm}\left(4^{\circ} \mathrm{C}\right)$ for $3 \mathrm{~min}$ and then washed 3 times in $5 \mathrm{~mL}$ phosphate-buffered saline $(0.9 \% \mathrm{NaCl})$, resuspended in $200 \mu \mathrm{L}$ phosphate buffer (Alvarez-Moya et al., 2001), and stored until use.

\section{Comet assay using Tradescantia}

The nuclear suspension was subjected to the comet assay as described by AlvarezMoya et al. (2001). Briefly, a layer of $1 \%$ normal melting point agarose was placed, allowed to solidify, and then retired for a completely clean surface. Afterwards, $300 \mu \mathrm{L} 0.6 \%$ low melting point (LMP) agarose was placed on the slide. A mixture was prepared with $250 \mu \mathrm{L} 0.5 \% \mathrm{LMP}$ agarose plus $10 \mu \mathrm{L}$ staminal nucleus suspension and placed on the first layer. Finally, a third layer of $100 \mu \mathrm{L} 0.5 \% \mathrm{LMP}$ agarose was added to cover the second layer.

Two slides were used for each concentration and were immersed in the alkaloid extracts, $1.0 \mathrm{mM}$ nitrosodimethylamine (positive control), and distilled water (negative control) for $3 \mathrm{~h}$. They were then washed with distilled water, placed in a lysis solution $[2.5 \mathrm{M} \mathrm{NaCl}, 100 \mathrm{mM}$ ethylenediaminetetraacetic acid (EDTA), $10 \mathrm{mM}$ Tris base, $1 \%$ lauroyl sarcosinate, $1 \%$ Triton $\mathrm{X}-100$, and $10 \%$ dimethyl sulfoxide, $\mathrm{pH} 10$ ] for $3 \mathrm{~h}$ at $4{ }^{\circ} \mathrm{C}$, and then washed with distilled water.

Immediately washing the slides, the gels were placed in the electrophoresis chamber (BioRad, Model A6) with cold running buffer (300 mM NaOH, $1 \mathrm{mM}$ EDTA, $\mathrm{pH}$ 13), for $45 \mathrm{~min}$ at $4{ }^{\circ} \mathrm{C}$ to allow denaturation and unwinding of the genetic material. In order to avoid additional damage to DNA, all of the steps described above were carried out under yellow light. Electrophoresis was performed for $10 \mathrm{~min}$ at $1.0 \mathrm{~V} / \mathrm{cm}$ and about $300 \mathrm{~mA}$ with a Labconco power source, model 4333280 . When the run time ended, the gels were washed with distilled water for $1 \mathrm{~min}$ and were immediately stained with ethidium bromide for $5 \mathrm{~min}$, washed twice with distilled water, and placed under a coverslip for observation. The comet assay was carried out using a fluorescence microscope (Axioskop 40) at 400X magnification with an excitation filter of 515-560 nm. The migration distance of the DNA was measured using the Comet Assay System II software.

\section{Statistical analysis}

The results are reported as means \pm standard deviation and were analyzed by one-way analysis of variance using the CoStat program (Ma et al., 1994). All experimental groups were compared with the corresponding negative control using the Dunnett test. One hundred nuclei were used for each concentration, and $\mathrm{P} \leq 0.05$ indicated statistical significance.

\section{RESULTS}

\section{Comet assay in staminal nuclei of Tradescantia}

Figure 1 shows the average migration of DNA in staminal nuclei of Tradescantia that were exposed to complete extracts of $L$. mexicanus, L. montanus, and different concentrations of sparteine and flavonoids for $3 \mathrm{~h}$. The $0.01,0.1,0.5$, and $1.0 \mathrm{mM}$ concentrations of $L$. 
mexicanus and L. montanus showed significant genotoxic activity $(\mathrm{P} \leq 0.05)$ compared to the negative control. Sparteine presented genotoxic activity only at $0.5 \mathrm{mM}$. With the exception of the $0.5 \mathrm{mM}$ concentration, the flavonoids showed no detectable genotoxic activity. The trend line indicated that the compounds, except sparteine, had the greatest genotoxic activity at the lowest concentrations. In addition, the extracts of $L$. mexicanus showed the highest genotoxic activity and was followed by L. montanus, flavonoids, and sparteine.
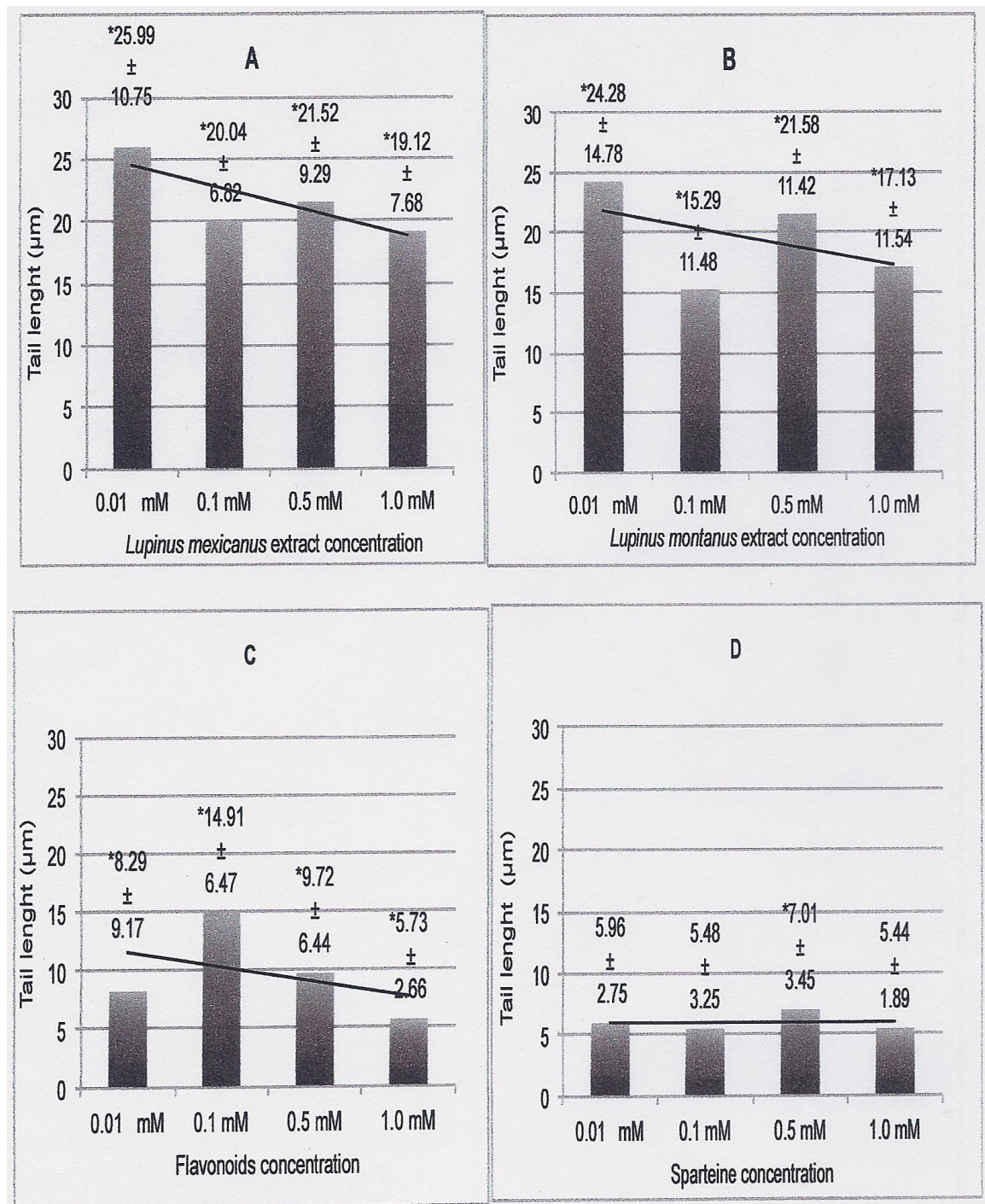

Figure 1. Average migration of the tail in staminal nuclei of Tradescantia (4430) exposed to whole extracts of (A) Lupinus mexicanus, (B) L. montanus, (C) flavonoids, and (D) sparteine. Asterisks indicate significant differences compared to the negative control $(\mathrm{P}<0.05)$. The mean tail length of the negative control (untreated staminal nuclei) was $6.53 \pm 3.13 \mu \mathrm{m}$, and the mean tail length of the positive control ( $1 \mathrm{mM}$ nitrosodimethylamine) was $29.62 \pm$ $8.32 \mu \mathrm{m}$ (data not shown). 


\section{DISCUSSION}

The high proportion of quinolizidine alkaloids in the seeds of wild lupines makes them toxic (Agid et al., 1988) and limits their direct use in food (Ruíz, 1994). Some studies suggested that L. montanus and L. mexicanus have genotoxic activity (Kinghorn and Balandrin, 1984; Ohmiya et al., 1995); however, their genotoxicity is not precisely known. Our results showed that all compounds that were studied except sparteine had strong genotoxic activity. In contrast, Quiles et al. (2010) reported that Lupinus termis lacked genotoxicity, and another study reported that it had an antigenotoxic effect (Farghaly and Hassan, 2012). The differences could be attributed to the different proportion of alkaloids between L. termis, L. mexicanus, and L. montanus. This is relevant because the genotoxic activity that was reported in our study shows a trend in which the genotoxic activity is inversely proportional to concentration: the genotoxic activity increased with decreasing concentrations. In previous studies (Rucinska and Gabryelak, 2009; Quiles et al., 2010), genotoxicity depended on the concentration. There are no previous reports of this behavior, but it is known that high doses of any genotoxic compound induce a high rate of breakage in DNA, which can cause extremely long tails that are not observable under the microscope, leading to a downward quantification of tails. Lower concentrations cause less severe genetic damage, producing more visible and apparently longer tails. This might explain the apparent paradox, as reported by Alvarez-Moya et al. (2001).

The concentrations that were used by Quiles et al. (2010) were relatively higher than those used here, and those concentrations would presumably not have allowed the detection of genotoxic activity in our system. In addition, the micronucleus and mouse lymphoma tests that are used to observe chromosome breaks are not the most efficient methods to detect gene mutations (Zuñiga, 2001).

Although sparteine and flavonoids have promising futures as drugs, more research is required to assess the risk that is posed by ingesting them (Porcher, 2007). Our results revealed that flavonoids have genotoxic activity, which was previously reported for the flavonoid genistein-8-C (Boos and Stopper, 2000); however, there are controversial data, specifically a difference between in vivo and in vitro studies (Rucinska and Gabryelak, 2009). It was not possible to define the genotoxicity of sparteine.

The Food and Drug Administration of the United States requires extensive toxicological studies to ensure that a product is not dangerous to human health. The data generated in this study are relevant to the decision to use these seeds for commercial purposes. Given the scarcity of data on the mutagenicity and effects of the alkaloids of L. montanus, L. mexicanus, and sparteine, it is clear that more genotoxicity studies are needed to further assess the potential danger associated with using Lupinus, especially because data varied between in vivo and in vitro studies (Rucinska and Gabryelak, 2009).

The detection of genotoxic activity may vary depending on the bioassay that is employed (Zuñiga, 2001). However, the comet assay is very efficient at detecting genotoxic agents (Golebiewski and Spenser, 1988; Singh et al., 1988; Henderson et al., 1998; AlvarezMoya et al., 2001). Therefore, the comet assay proved to be ideal for assessing the genotoxicity of alkaloids.

The assessment of extracts of L. mexicanus, L. montanus, and flavonoids showed genotoxic activity with low concentrations in the nuclei of Tradescantia. The differences between this and other reports could be attributed to several factors, including the different concentrations of alkaloids in species; the different test systems that were used; excessive induced 
genetic damage, which weakens the correct detection of the tails in the nuclei employed; and the different concentrations of extracts that were used. The comet assay is an excellent tool for detecting genotoxic activity, and it is convenient for the study of alkaloids. However, because of its high sensitivity, it is desirable to use it only to study very low concentrations of compounds.

\title{
ACKNOWLEDGMENTS
}

\author{
Research partially supported by CONACYT-COECYTJAL 2009, México.
}

\section{REFERENCES}

Agid Y, Pertuiset B and Dubois B (1988). Motoneuron disease as manifestation of lupin seed toxicity. Lancet 1: 1347.

Alvarez-Moya C, Santerre-Lucas A, Zúñiga-González G, Torres-Bugarín O, et al. (2001). Evaluation of genotoxic activity of maleic hydrazide, ethyl methane sulfonate, and N-nitroso diethylamine in Tradescantia. Salud Pública Mexico 43: 563-569.

Belpaeme K, Cooreman K and Kirsch-Volders M (1998). Development and validation of the in vivo alkaline comet assay for detecting genomic damage in marine flatfish. Mutat. Res. 415: 167-184.

Bermúdez-Torres K, Herrera JM, Brito RF, Wink M, et al. (2009). Activity of quinolizidine alkaloids from three Mexican Lupinus against the lepidopteran crop pest Spodoptera frugiperda. Biocontrol 54: 459-466.

Boos G and Stopper H (2000). Genotoxicity of several clinically used topoisomerase II inhibitors. Toxicol. Lett. 116: 7-16.

Bunger A, Soto D, Witting E, Cariaga L, et al. (1999). Development of food products containing lupin fiber and their effects in elderly people. In: Proceedings of the 9th International Lupin Conference, Klink/Muritz.

Dash AA and Sgarbieri VC (1980). Sweet lupine-fortified bread: nutritional value and amino acid content. Cereal Chem. 57: 9-11.

Dunn DB (1979). Lupinus. In: Flora fanerogámica del Valle de México (Rzedowski J and Rzedowski GC, eds.). Compañía Editorial Continental, SA México, Distrito Federal, 326-338.

Egaña J, Uauy R, Cassorla X, Barrera G, et al. (1992). Sweet lupin protein quality in young men. J. Nutr. 122: 2341-2347.

Farghaly AA and Hassan ZM (2012). Methanolic extract of Lupinus termis ameliorates DNA damage in alloxan-induced diabetic mice. Eur. Rev. Med. Pharmacol. Sci. 16: 126-132.

Gladstones J (1974). The Mediterranean white lupin. Department of Agriculture, Western Australia Technical Bulletin, Western Australia, 26: 70-74.

Gladstones J (1998). Distribution, origin, taxonomy, history and importance. In: Lupinus as crop plants: biology, production and utilization (Glandstones J, Atkins J and Hamblin C, eds.). Cab International, New York, 1-39.

Golebiewski WM and Spenser ID (1988). Biosynthesis of the lupine alkaloids. II. Sparteine and lupanine. Can. J. Chem. 66: $1734-1748$

Henderson L, Wolfreys A, Fedyk J, Bourner C, et al. (1998). The ability of the Comet assay to discriminate between genotoxins and cytotoxins. Mutagenesis 13: 89-94.

Kinghorn A and Balandrin M (1984). Quinolizidine alkaloids of the Leguminosae: structural types, analysis, chemotaxonomy, and biological activities. In: Alkaloids: Chemical and biological perspectives (Pelletier S, ed.). Wiley, New York, 105-148.

Koppen G and Verschaeve L (1996). The alkaline comet on plant cells: a new genotoxicity test for DNA breaks in Vicia faba roots cells. Mutat. Res. 360: 193-200.

López-Bellido L and Fuente M (1986). Lupin crop as an alternative source of protein. Adv. Agron. 40: 239-289.

Ma TH, Cabrera GL, Cebulska-Wasilewska A, Chen R, et al. (1994). Tradescantia stamen hair mutation bioassay. Mutat. Res. 310: 211-220.

McVaught R (1987). Leguminosae. In: Flora Novo-Galiciana 5 (Anderson WR, ed.). University of Michigan Herbarium Press, Ann Arbor.

Nacci DE, Cayula S and Jackim E (1996). Detection of DNA damage in individual cells from marine organisms using the single cell gel assay. Aquat. Toxicol. 35: 197-210.

Ohmiya S, Saito K and Murakoshi I (1995). Lupine alkaloids. In: Alkaloids (Cordell G, ed.). Academy Press, New York, 1-114.

Porcher MH (2007). Sorting Lupinus names (Multilingual Multiscript Plant Name). The University of Melbourne, 
Australia (TUMA). http://www.ars.grin.gov/misc/mmpnd/lupinus.html. Accessed May 14, 2013.

Prakash AS, Pereira TN, Reilly PE and Seawright AA (1999). Pyrrolizidine alkaloids in human diet. Mutat. Res. 443: 53-67.

Quiles MRS, Oquendo-Jiménez I, Herreño-Saénz D and Antoun MD (2010). Genotoxicity of alkaloid-rich extract from Lupinus termis seeds. Pharm. Crops 1: 18-23.

Rucinska A and Gabryelak T (2009). Effect of genistein-8-C-glucoside from Lupinus luteos on DNA damage assessed using the comet assay in vitro. Cell Biol. Int. 33: 247-252.

Ruíz L (1994). Disponibilidad nutricional de tres especies silvestres de Lupinus (Leguminosae) del estado de Jalisco. Master's thesis, Guadalajara.

Singh NP, McCoy MT, Tice RR and Schneider EL (1988). A simple technique for quantitation of low levels of DNA damage in individual cells. Exp. Cell Res. 175: 184-199.

Stobiecki M, Wojtaszek P and Gulewicz K (1997). Application of solid phase extraction for profiling quinolozidine alkaloids and phenolic compounds in Lupinus albus. Phytochem. Anal. 8: 153-158.

Wink M and Hartmann T (1981). Sites of enzymatic synthesis of quinolizidine alkaloids and their accumulation in Lupinus polyphyllus. Z. Pflanzenphysiol. 102: 337-344.

Wojakowska A, Perkowski J, Góral T and Stobiecki M (2013). Structural characterization of flavonoid glycosides from leaves of wheat (Triticum aestivum L.) using LC/MS/MS profiling of the target compounds. J. Mass Spectrom. 48: 329-339.

Wysocka W and Przybyl A (1994). Alkaloids from Lupinus albus and Lupinus angustifolius L.: an efficient method of extraction. Sci. Legumes 1: 37-50.

Zuñiga G (2001). Sistemas para la detección de daño genético. In: Genética Ambiente y Salud. 2nd edn. (Alvarez MC, ed.). Universidad de Guadalajara, Guadalajara, 127-150. 